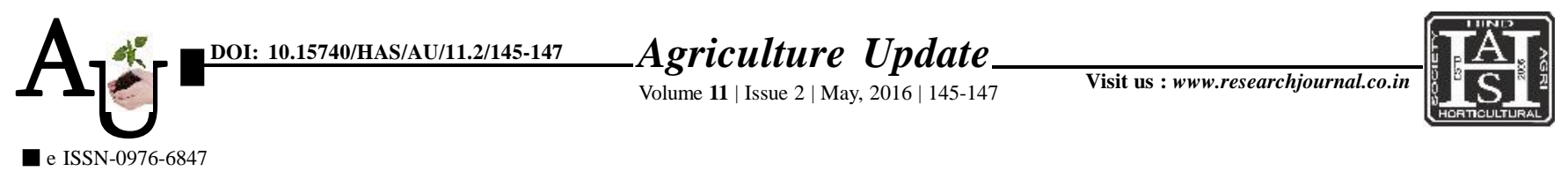

\title{
Rвевавсн АвтісL: : To examine the pattern and composition of woman labour employed in Latur district
}

R.D. SHELKE AND J.P. MOHITE

Article Chronicle :

Received :

20.12.2015;

Revised :

14.03.2016;

Accepted :

15.04.2016

KEY WoRDS :

Pattern,

Composition,

Women labourer,

Employment harvest operations. 147).
SUMMARY : In this paper an attempt has been made to study the pattern and composition of woman labourer employed. The present study conducted in Latur district from Marathwada region of Maharashtra state. 60 women labourers were selected from 10 villages of two blocks for the study. The result revealed that the labourers got maximum number of days of employment in harvesting (52.17 days) which accounted for 24.92 per cent of total days employed in a year in agriculture, followed by weeding (49.08 days) which accounted for 23.44 per cent of total days employed in a year in agriculture, sowing (31.39 days), threshing and winnowing (26.48 days), application of fertilizers (21.68 days), Stubble collection (15.07 days), Thinning and gap filling (13.5 days). The women labourers did the operations mostly by hand. They received wages in cash for all operations except harvest and post

How to cite this article : Shelke, R.D. and Mohite, J.P. (2016). To examine the pattern and composition of woman labour employed in Latur district. Agric. Update, 11(2): 145-147 (DOI: 10.15740/HAS/AU/11.2/145-
Author for correspondence :

\section{J. P. MOHITE}

Department of Agricultural Economics, College of Agriculture, LATUR (M.S) INDIA

Email: jyoti.mohite24@ rediffmail.com

See end of the article for authors' affiliations 